IJLRES - International Journal on Language, Research and Education Studies

ISSN: 2580-6777 (p); 2580-6785 (e)

DOI: $10.30575 / 2017 /$ IJLRES-2018091209

Vol. 2, No. 3, 2018

Page: $408-419$

\title{
CHILDREN'S LEGAL AND AUTHORITIES STATUS OF THE DEVOTIVE MARRIAGE RESULTS BECAUSE OF THE CANCELLATION OF MARRIAGE BASED ON REGULATION NO.1 YEAR 1974 AND ISLAMIC LAW COMPILATION IN INDONESIA
}

\author{
Aisyah \\ The University of Prima Indonesia \\ aisyahshmh@gmail.com
}

\begin{abstract}
Absract, This study aims to find out about the position of the child of the result of a broken marriage due to the existence of cancellation, and the inheritance position of a child who is a result of a broken marriage due to a marriage cancellation The method used in writing this Journal is a qualitative method with data collection techniques is library research collected and analyzed with descriptive techniques. The results of the study show that the Nasab position of a child who has a broken marriage due to a marriage cancellation is attributed to his father and mother, this is based on Article 28 of Law No. 1 of 1974 and Article 75 of the Compilation of Islamic Law affirms that the cancellation of a marriage based on a court decision does not apply retroactively to the children born from the marriage. The inheritance of a child who has a broken marriage due to a marriage cancellation can still inherit the property from his father or mother and also the child has a family relationship with the family of the father or mother.
\end{abstract}

Keyword: Children's Legal And Authorities Status, The Devotive Marriage, Islamic Law Compilation.

\section{PENDAHULUAN}

Islam keeps the offspring with care since the child is in the womb until the child is an adult. Islam is a religion that is very concerned about the protection and safeguarding of human rights from the time of its creation (the womb) to its death. Children are prizes from God that are invaluable, for that as parents are required to care for, and nurture them with love, do not let children born wasted by both parents, even abandoned.

In essence the child is born in this world in a sacred state, just how the parents who direct, are directed to the Christian or Christian or to the path of Islam. For this reason parents are very instrumental in forming the character of a child.

Basically Islamic marriage law is known as a principle called selectivity. It means that, when someone wants to get married, they must first choose whom they can marry and with whom they are forbidden to marry. This is to ensure that the marriage that is 


\section{Children's Legal and Authorities Status of the Devotive Marriage Results Because of the Cancellation of Marriage Based on Regulation No.1 year 1974 and Islamic Law Compilation in Indonesia \\ DOI: 10.30575/2017/IJLRES-2018091209}

held does not violate the existing rules. Especially if women who want to marry are forbidden to marry, which in Islam is known as the mahram (the person who is forbidden to be married). ${ }^{1}$

Marriage automatic damage has due to provisions violate. There are many possibilities for marriage with fellow mahram. Or even a marriage that is carried out without regard to the stipulated terms and conditions of marriage. Ignorance and love can be a contributing factor. Ignorance that it turns out that the bridegroom and the bride are mahram or that nothing else can cancel the marriage can still be considered an understandable mistake. The law of sin cannot be dropped because of that ignorance. However, if love is used as an excuse to continue to get married, then this is a big mistake.

Departing from the cancellation of the marriage caused by a prohibition or barrier, from there arises a problem what if the child is born from a canceled marriage because of a barrier in marriage. The researcher was interested in examining how the status of a broken child as a result of the existence of marital barriers and how the inheritance position of a child who is a result of a broken marriage is due to the presence of marital barriers.

\section{LITERATURE REVIEW}

\section{Definition of Legitimate Child}

Islamic law affirms that a child can be considered a legitimate child, must be born at least six months after the marriage is held or in the grace period for four months and ten days after the marriage is cut off. ${ }^{2}$

The view of fiqh concerning the legitimate child starts from the conception or fertilization of the egg (ovum) by sperm which occurs in the womb of the prospective mother with conception occurring in a legitimate marriage. ${ }^{3}$

\footnotetext{
${ }^{1}$ Mohd. Idris Ramulyo, Hukum Perkawinan Islam: Suatu Analisis dari Undang-Undang No. 1 Tahun 1974 dan Kompilasi Hukum Islam, (Jakarta : Bumi Aksara, 1996), pp 34.

${ }^{2}$ Wirjono Prodjodikoro, Hukum Perkawinan di Indonesia (Bandung : Sumur, 1960), hal. 72.

${ }^{3}$ Mustofa Rahman, Anak Luar Nikah; status dan Implikasi Hukumnya (Jakarta: Atmaja, 2003), pp. 45 .
} 
Article 42 of Law Number 1 of 1974 concerning Marriage states that a legitimate child is a child born in or as a result of a legitimate marriage. ${ }^{4}$ Furthermore, Article 43 of Law Number 1 of 1974 concerning Marriage confirms that a child born outside of marriage only has a civil relationship with his mother and his mother's family.

The compilation of Islamic Law also states that a legitimate child is a child born within or due to a legal marriage, and is the result of conception of a legitimate husband and wife outside the womb and who was born by the wife. Children born outside of marriage only have a relationship with their mothers and their mothers' families. 5

A husband can deny the legitimacy of the child born to his wife, if he can prove that his wife has committed adultery and the child is the result of the adultery. The court will give a decision about whether or not the child is legitimate at the request of the parties concerned. 6

A husband who denies that the child born to his legitimate wife is his child, and then his wife does not deny it, the husband can confirm his denial by means of Allah. A husband who will deny a child born to his wife submits a lawsuit to the Religious Court within 180 days of his birth or 360 days after his marriage is terminated or after the husband learns that his wife gave birth to a child and allows him to submit his case to the Court Religion. Denial submitted by the husband after the past period of time 180 days after the day of birth or 360 days after the termination of the marriage is unacceptable and automatically the child is a legally recognized child. ${ }^{7}$

\section{Children's Rights and Obligations}

Article 46 of Law Number 1 Year 1974 gives obligations to children to always respect their parents and obey their good will. If the child is an adult, he must maintain according to his ability, parents and family in a straight line up, if they need his help. ${ }^{8}$

Abdur Rozak in his book "Children's Rights in Islam" argues that children have rights: ${ }^{9}$

\footnotetext{
${ }^{4}$ See artilel 42 Law number 1 year 1974

${ }^{5}$ See aricle 99 of the compilation of Islamic Law

${ }^{6}$ See article 44 Law number 1 year 1974

${ }^{7}$ See article 101-102 of the compilation of Islamic law

${ }^{8}$ See article 46 Law number 1 year 1974

${ }^{9}$ Abdur Rozak Husein, Hak Anak Dalam Islam, (Jakarta : Fikahati Aneska, 1992), pp. 21.
} 


\section{Children's Legal and Authorities Status of the Devotive Marriage Results Because of the Cancellation of Marriage Based on Regulation No.1 year 1974 and Islamic Law Compilation in Indonesia \\ DOI: 10.30575/2017/IJLRES-2018091209}

1. Children's rights before and after birth.

2. Rights of the child in the sanctity of his offspring.

3. Children's rights to receive a good name.

4. Children's rights to accept breastfeeding.

5. Children's rights in obtaining care, care and maintenance.

6. Children's rights in the possession of property or inheritance rights for their survival.

7. Children's rights in education and teaching.

Jurisprudence scholars emphasize that the relationship between parents and children will lead to children's rights to their parents, namely :10

1) Right of Rada

Right of Rada' means the right of the child to get basic food service by breastfeeding his mother. And in this period of time the responsible person in terms of financing is the closest relatives according to the nasab line and in this case the father has the position.

2) Right of Hadanah

Hadanah means putting something near the ribs like carrying it, or putting something in your lap. According to figh terms, hadlanah is the task of maintaining and nurturing or educating infants or young children since he was born to be able to maintain and manage himself.

3) Right Walayah

In the care of children from small to high levels besides having hadlanah rights there is also a guardianship right. The duty of guardianship in addition to understanding in marriage, also for the duty of caring for the child since the end of the hadlanah period until he is intelligent, or until marriage to a daughter and guardianship in matters of wealth.

4) Right of Livelihood

${ }^{10}$ Mohammad Thalib. (Trans) Sayyid Sabiq, Fikih Sunnah 8, (Bandung : PT. Alma'arif, 1980), Cet 15 , pp. 173. 


\section{Aisyah}

The right to earn a living is the right of the child who is directly related to nasab. As soon as a child is born, the right to live has begun to be fulfilled. These children's livelihood rights are interrelated with each of the rights above.

\section{Cancellation of Marriage Islamic Perspective}

The cancellation of marriage is also called by fasakh. Fasakh marriage is to decide or cancel the relationship between husband and wife because of the conditions or harmony that is not fulfilled. The understanding of fasakh according to the meaning of the language is null or damaged while in the term syar'i is the cancellation or termination of marriage with a Qodhi's decision ${ }^{11}$ atau :

$$
\text { فسح العقد نقضه وحل الرابطة التى تربط بين الزوجين( فقه سنه) }
$$

Faskhul Aqdhi, namely the cancellation of the marriage and the breaking of the binding rope between husband and wife. ${ }^{12}$

Fasakh can be occurred because the conditions are not fulfilled when the marriage contract takes place, or because of other things that come later and cancel the marriage continuity. ${ }^{13}$

a. Fasakh (cancellation of marriage) because the conditions are not met when the marriage contract.

1. After the marriage contract, it turns out it is known that his wife is a sibling or sibling of the husband's side.

2. The husband and wife are still small, and the marriage contract is held by a father or his father. Then after an adult he has the right to continue his previous marriage bond or end it. This method is called khiyar baligh. If the chosen one ends the bond between husband and wife, then this is called fasakh baligh.

b. Fasakh because of things that come after the contract.

\footnotetext{
${ }^{11}$ M. Anwar, Dasar-Dasar hukum Islam dalam Menetapkan Keputusan di Pengadilan Agama (Bandung: CV. Diponegoro, 1991), pp73

${ }^{12}$ Sayyid Sabiq, Fiqh Sunnah VIII, Alih bahasa M. Tholib (Bandung : PT. Al-MA'arif, 1993), pp. 124

${ }^{13}$ Dr. H. Abd. Rahman Ghazaly M.A., Fiqh Munakahah Seri Buku Daras (Jakarta : Kencana), pp.
} 


\section{Children's Legal and Authorities Status of the Devotive Marriage Results Because of the Cancellation of Marriage Based on Regulation No.1 year 1974 and Islamic Law Compilation in Indonesia \\ DOI: 10.30575/2017/IJLRES-2018091209}

1. If one of the husband and wife falls away or leaves the religion of Islam and does not want to return at all, then the contract is canceled due to apostasy that occurred later.

2. 2. If the husband who was once an infidel converted to Islam, but the wife is still in disbelief that is to remain polytheistic, then the contract is null and void. Another case if the wife of an expert on the book, the contract remains valid as before. Because his marriage to the scribe was originally considered legitimate. ${ }^{14}$

\section{Cancellation of Marriage Positive Legal Perspective in Indonesia}

The provisions of Law No. 1 of 1974 provide a review of the reasons for the cancellation of marriage, namely:Perkawinan dilangsungkan di bawah ancaman yang melanggar hukum (pasal 27 UU No. 1/1974).

a. One party falsified his identity (Article 27 of Law No. 1/1974). False identities such as status, age, name or religion.

b. Husbands / wives who still have marital ties do marriage without the permission and knowledge of other parties (article 24 of Law No. 1 of 1974).

c. Marriage that is not in accordance with the marriage requirements (Article 22 of the Marriage Law)

In line with the provisions of Law No. 1 of 1974 above, the Compilation of Islamic Law has also been refined related to the annulment of marriage into two categories namely Marriage which is null and void, and which can be canceled.

\section{FINDINGS AND DISCUSSION}

The position of the Nasab of a broken child resulting from the cancellation of marriage.

The position of the child is legally considered valid if the child is born from a legal marriage. A legal marriage is a marriage that fulfills the conditions stipulated in article 6 of the marriage law. Basically a broken marriage either because of death, divorce or the cancellation of marriage will bring legal consequences to the position of the

\footnotetext{
${ }^{14}$ Sayyid Sabiq, Fiqh Sunnah cet ke- 4 jilid II (Beirut : Dar Al- Fikr, 1983), pp. 268
} 


\section{Aisyah}

husband and wife, the position of the child and the position of shared assets or assets that exist during marriage.

The husband and wife whose marriage is aborted will result in the marriage as if there has never been or has never happened between the two, but the marriage has been canceled and will not break the legal relationship between the child and his parents.

Article 28 of Law no. 1 of 1974 and Article 75 of the Compilation of Islamic Law affirms that the cancellation of a marriage based on a court decision does not apply retroactively to the children born from the marriage.

The above provisions illustrate that the status of a child is still entitled to legal protection and full recognition from the government and from his parents. The position of the child remains legally valid even if the marriage of their parents is deemed to have never existed (null and void) because the child was born from a legitimate marriage beforehand. Compilation of Islamic Law also emphasizes that the cancellation of a marriage will not break the legal relationship between the child and his parents. ${ }^{15}$

\section{Position of Inheritance from Discontinued Marital Children Due to Marriage Obstacles.}

As already explained, marriage can be canceled if the parties do not meet the conditions for a marriage or there has been a violation of the provisions of both pillars and legal requirements for marriage.

Basically a broken marriage, either because of death, divorce or cancellation, will have legal consequences for the position of the husband and wife, the position of the child and joint assets or assets that exist during the marriage. With regard to the problem of the position of the child regulated in Law No. 1 of 1974, namely in Chapter IX articles 42 to 47.

In article 42 says that, legitimate children are children born or as a result of legal marriage. While a legitimate marriage is a marriage that fulfills the conditions stipulated in article 6 of the Marriage Act. The same is true of children born from the consequences of being canceled between their parents. As explained in article 28 of Law No. 1 of 1974, the cancellation of a marriage begins after a court decision has permanent legal force and is valid from the time the marriage takes place. This means that what is canceled is where the marriage took place, namely when the marriage contract took place between the

\footnotetext{
${ }^{15}$ See article 76 of the compilation of Islamic law
} 


\section{Children's Legal and Authorities Status of the Devotive Marriage Results Because of the Cancellation of Marriage Based on Regulation No.1 year 1974 and Islamic Law Compilation in Indonesia DOI: 10.30575/2017/IJLRES-2018091209}

husband and wife who were canceled before the existence of the child and after the existence of the child and when the decision was made it did not apply retroactively to the children born in it.

Husbands and wives whose marriages are aborted will cause the two of them to appear as if there has never been or occurred a marriage between the two but although a cancellation is basically aimed at returning the situation as when the deed was canceled it has not yet occurred may assume as if there has never been a marriage because many interests of various parties must be protected.

In jurisprudence, there are actually two different terms, even though the law is the same, namely al-fasid marriage and al-batil marriage. Al-Jaziry stated that facade marriage is a marriage that does not fulfill one of the conditions of the conditions, whereas vanity marriage is if it is not fulfilled in harmony. The marriage law of Fasid and Batil is equally illegitimate. ${ }^{16}$

And the implication of fascist marriage or physical marriage here can be canceled if there has been a marriage or prevented if there are violations of marital material, such as there are marriage restrictions. But different from the perspective of fiqh Law No. 1 of 1974 did not recognize the existence of harmony in marriage. It seems that Law No. 1 of 1974 only contains matters relating to marriage requirements.

According to Islamic Law, the separation of husband and wife due to the cancellation of marriage or fasakh has separate differences caused by divorce. If there is a fasakh in the form of a violation of the marriage law or the presence of barriers that do not allow continuing the marriage, the legal consequences occur. Especially the legal consequences caused by the termination of the marriage in a fasakh was that the husband could not go to his ex-wife as long as the wife was undergoing the iddah period, because the divorce in the form of the fasakh was ba'in sughro. If the ex-husband and ex-wife want to continue their marriage, they must make a new marriage contract, both in the time the ex-wife goes through the iddah period of the husband or after the completion of the iddah period. ${ }^{17}$ t.t), h. 118 .

${ }^{16}$ Abdurrahman Al-Jaziry, Kitab al-Fiqh 'ala Mazahib al-Arba'ah, Juz IV (Beirut: Dar al-Fikr,

${ }^{17}$ Prof Dr,Amir Syarifuddin, Hukum Perkawinan Islam Di Indonesia : Antara Fiqh Munakahah dan UUP (Jakarta : Kencana, 2007) cet II, h. 253 


\section{Aisyah}

As for National law, namely Law No. 1 of 1974 and KHI, a marriage which is later canceled has civil consequences, both for husband and wife and for their children provided that the marriage is carried out in good faith. But if the good faith is only on one side, Article 96 BW determines that the party that applies in good faith has only a favorable civil effect, as does the children.

But if the good faith is only available to one party, then the party with bad intentions will consequently be borne as well. According to article 28 of Law No. 1 of 1974, the cancellation of a marriage begins after a court decision has permanent legal force, and is valid from the time the marriage takes place. This means the court decision is retroactive. And the exception to retroactive are:

a. Children born from the marriage.

b. Husbands or wives who act in good faith, except for shared assets, if the cancellation of marriage is based on the existence of another marriage in advance.

c. Other third people are not included in groups (a) and (b) as long as they obtain the rights in faith before the decision on the annulment of the marriage has permanent legal force.

Related to the problem of the position of the child, whether the child was given to his father or only to his mother, it seems that KHI and BW are in line with what is stipulated in Law No. 1 of 1974 which is seen in article 75 KHI, that the decision to cancel marriage is not retroactive to;

a. Marriage is canceled because one of the husband or wife is an apostate;

b. Children born from the marriage;

c. Third parties insofar as they obtain rights in good faith, before the decision to cancel marriage has permanent legal force.

Furthermore in article $76 \mathrm{KHI}$ provides information that "the cancellation of a marriage will not break the legal relationship between the child and his parents". As explained in Law No. 1 In 1974 and KHI children did not apply retroactively to the consequences of the cancellation of the marriage that occurred. So the status of the child is still entitled to legal protection and recognition that is fully from the government and from the parents of the child remains legal even though their parents' marriage is deemed to have never existed (null and void) because the child was born from a legal marriage as explained in article 42 Law No. 1 of 1974 and articles 75 and 76 of KHI. 


\section{Children's Legal and Authorities Status of the Devotive Marriage Results Because of the Cancellation of Marriage Based on Regulation No.1 year 1974 and Islamic Law Compilation in Indonesia \\ DOI: 10.30575/2017/IJLRES-2018091209}

So for children who are already born after the court cancels the marriage of their parents, the children are still considered legitimate children. This is based on the humanitarian values and interests of the child when he grows up, so that he has legal protection. So in the case of nasab and guardianship, it is still attributed to his father or man who aggravates his mother, and the child can inherit property from his father or mother and also the child has a family relationship with the family of the father (mother). Unlike out-of-wedlock children who only have civil relations with their mothers as stated in article 43 paragraph (1) Law No. 1 of 1974.

The things mentioned above apply when the cancellation of marriage occurs due to violations in formal and material conditions (permanent prohibition), because it is not mentioned in detail in Law No. 1 of 1974 and KHI concerning the differences in the position of children because the marriage violates the formal requirements and material requirements.

Thus, the position of inheritance from a child who has a broken marriage due to the existence of marital barriers. Keep getting inheritance as a child in general, as long as the child does not have inheritance barriers as the provisions stated in the aspect of inheriting requirements.

\section{CONCLUSION}

From the previous discussions, conclusions can be drawn as follows:

1. The Nasab position of a child who has a broken marriage due to the cancellation of marriage is attributed to his father and mother, this is based on Article 28 of Law no. 1 of 1974 and Article 75 of the Compilation of Islamic Law affirms that the cancellation of a marriage based on a court decision does not apply retroactively to the children born from the marriage.

2. The inheritance of a child who has a broken marriage due to a marriage cancellation that the child can still inherit property from his father or mother and also that the child has a family relationship with the family of the father (mother). 


\section{Aisyah}

\section{BIBILIOGRAPHY}

Abd. Rahman Ghazaly M.A., Figh Munakahah Seri Buku Daras (Jakarta : Kencana.

Abdurrahman. Kompilasi Hukum Islam, Jakarta : Akademika Pressindo, 1992

Affandi, Ali. Hukum Waris, Hukum Keluarga, Hukum pembuktian, Jakarta : Bina Aksara, 1986.

Al-Jaziry, Abdurrahman. Kitab al-Fiqh 'ala Mazahib al-Arba'ah, Beirut: Dar al-Fikr, t.t.

Anwar, M. Dasar-Dasar hukum Islam dalam Menetapkan Keputusan di Pengadilan Agama, Bandung: CV. Diponegoro, 1991.

Ayyub, Syaikh Hasan. "Fiqhul Usroh Al-Muslimah", diterjemahkan M. Abdul Ghoffar, FikihKeluarga, Jakarta: Pustaka Al-Kautsar, 1999.

Fayumi, Badriyah. "Incest dan Perlindungan Perempuan", dalam Swara Rahima, No. 8 Tahun III Agustus 2003, h. 15. Lihat juga, Muhammad Bagiq al-Habsyi, Fiqh Praktis Menurut alQur'an, as-Sunnah, dan Pendapat Para Ulama (Buku Kedua), Bandung: Mizan Media Utama, cet. I, 2002.

Husein, Abdur Rozak. Hak Anak Dalam Islam, Jakarta : Fikahati Aneska, 1992.

Idris Ramulyo, Mohd. Hukum Perkawinan Islam: Suatu Analisis dari Undang-Undang No. 1 Tahun 1974 dan Kompilasi Hukum Islam, Jakarta : Bumi Aksara, 1996.

Nuruddin, Amiur. Akmal Tarigan, Azhari. Hukum Perdata Islam di Indonesia Studi Kritis Perkembangan Hukum Islam dan Fikih Undang-Undang No. 1 Tahun 1974 sampai KHI, Jakarta : Kencana, 2006.

Nuruddin, Amiur. Hukum Perdata Islam di Indonesia, (Studi Kritis Perkembangan Hukum Islam dari Fikih, UU No. 1/1974 sampai KHI), Jakarta: Prenada Media, 2004.

Prodjodikoro, Wirjono. Hukum Perkawinan di Indonesia, Bandung : Sumur, 1960.

Rahman Ghazaly, Abd. Fiqh Munakahat Seri Buku Daras, Jakarta: Kencana, 2006.

Rahman, Mustofa. Anak Luar Nikah; status dan Implikasi Hukumnya, Jakarta: Atmaja, 2003.

Sabiq, Sayyid, Figh Sunnah VIII, Alih bahasa M. Tholib, Bandung : PT. Al-MA'arif, 1993.

Sabiq, Sayyid. Fiqh Sunah cet ke- 4 jilid II, Beirut : Dar Al- Fikr, 1983.

Sastromodjo, Hukum Perkawinan di Indonesia, Jakarta: Bulan Bintang ,1978. 
Children's Legal and Authorities Status of the Devotive Marriage Results Because of the Cancellation of Marriage Based on Regulation No.1 year 1974 and Islamic Law

Compilation in Indonesia

DOI: 10.30575/2017/IJLRES-2018091209

Syarifuddin, Amir. Hukum Perkawinan Islam Di Indonesia : Antara Figh Munakahah dan UUP, Jakarta: Kencana, 2007.

Thalib, Mohammad. (Trans) Sayyid Sabiq, Fikih Sunnah 8, Bandung : PT. Alma'arif, 1980.

Undang - undang No. 1 Tahun 1974 Tentang Perkawinan

The Compilation of Islamic Law (Kompilasi Hukum Islam - KHI) 